\title{
Analisa Keruntuhan Bendungan Salomekko Kabupaten Bone Dengan Menggunakan Aplikasi Zhong Xing HY21
}

\author{
Mirsa Ayu $^{1 *}$, Pitojo Tri Juwono ${ }^{1}$, Runi Asmaranto ${ }^{1}$ \\ ${ }^{1}$ Jurusan Teknik Pengairan, Fakultas Teknik, Universitas Brawijaya, \\ Jalan MT. Haryono No. 167, Malang, 65145, INDONESIA \\ *Korespondensi Email: mirsaayu_06@student.ub.ac.id
}

\begin{abstract}
The Salomekko Dam is located in the Salomekko Hamlet of Ulu Balang Village, Salomekko District, Bone Regency, South Sulawesi Province which has the main pupose of providing water for agricultural irrigation of 1722 hectares. Besides having the benefit of the Salomekko Dam, it also has potential dangers, namely if the dam collapses. Therefore, it is necessary to dam break analysis of the Salomekko Dam which is assumed to be due to overtopping and pipping using the Zhong Xing HY21 application. Based on the simulation results through the Zhong Xing HY21 application, the collapse due to overtopping was the cause of the collapse of the Salomekko Dam which had the greatest impact with the PMF design flood discharge of $753.862 \mathrm{~m}^{3} / \mathrm{s}$ and an inundation area of $15.694 \mathrm{~km}^{2}$ with a maximum inundation height of $7.759 \mathrm{~m}$. The collapse of the Salomekko Dam resulted in 11 villages being affected on the downstream side of the dam with the population at risk of 2565 people.
\end{abstract}

Keywords: Dam Break, Salomekko Dam, Zhong Xing HY21

\begin{abstract}
Abstrak: Bendungan Salomekko terletak di Dukuh Salomekko Desa Ulu Balang, Kecamatan Salomekko, Kabupaten Bone, Provinsi Sulawesi Selatan yang memiliki fungsi utama untuk menyediakan air bagi kebutuhan irigasi pertanian seluas $1722 \mathrm{Ha}$. Bendungan Salomekko disamping memiliki manfaat juga menyimpan potensi bahaya, yaitu apabila bendungan runtuh. Oleh karena itu, dibutuhkan analisa keruntuhan bendungan Bendungan Salomekko yang diasumsikan akibat overtopping dan pipping menggunakan aplikasi Zhong Xing HY21. Bedasarkan hasil simulasi melalui aplikasi Zhong Xing HY21, keruntuhan akibat overtopping merupakan peyebab keruntuhan Bendungan Salomekko yang menimbulkan dampak paling besar dengan debit banjir rancangan PMF sebesar 753,862 m³/det dan luas genangan 15,694 $\mathrm{km}^{2}$ dengan tinggi genangan maksimum 7,759 m. Keruntuhan Bendungan Salomekko mengakibatkan 11 desa terdampak pada bagian hilir bendungan dengan jumlah penduduk terkena resiko 2565 jiwa.
\end{abstract}

Kata kunci: Bendungan Salomekko, Keruntuhan Bendungan, Zhong Xing HY21 


\section{Pendahuluan}

Seiring dengan perkembangan zaman kebutuhan akan pasokan air semakin meningkat, maka salah satu cara dalam peningkatan sektor sumber daya air untuk memenuhi kebutuhan akan air hingga untuk mendukung ketahanan pangan adalah dengan membangun sarana dan prasarana fisik untuk menunjang pemanfaatan air yaitu bendungan. Pembangunan sebuah bendungan selain ditujukan untuk memperoleh manfaat tertentu, namun juga menyimpan potensi keruntuhan yang dapat menyebabkan kerugian yang begitu besar[1]. Jika terdapat fenomena alam yang seringkali sulit diprediksi dan apabila bendungan tidak dikelola dengan baik, maka suatu bendungan akan mengalami keruntuhan sehingga menyebabkan banjir yang sangat besar sehingga mampu menimbulkan kerugian besar di bagian hilirnya. Sama seperti kejadian terdahulu yaitu runtuhnya Bendungan Situ Gintung tahun 2009 silam yang mengakibatkan korban meninggal 98 orang dan 115 hilang.

Bendungan Salomekko terletak di Dukuh Salomekko, Desa Ulu Balang, Kecamatan Salomekko, Kabupaten Bone, Provinsi Sulawesi Selatan yang memiliki berguna untuk memberikan air dalam memenuhi kebutuhan irigasi pertanian seluas 1722 Ha. Selain bermanfaat, Bendungan Salomekko juga memiliki potensi bahaya yang sangat besar apabila terjadi runtuhnya suatu bendungan. Menurut penelitian yang dilakukan oleh Costa, penyebab keruntuhan bendungan urugan umumnya diakibatkan oleh overtopping dan juga piping. Kondisi overtopping terjadi apabila air melimpas melalui puncak bendungan sedangkan piping diakibatkan oleh bocoran atau rembesan melalui tubuh bendungan.

Oleh karena itu perlu adanya analisa keruntuhan bendungan (Dam Break Analysis) dan simulasi keruntuhan bendungan (Dam Break Simulation). Analisa keruntuhan Bendungan Salomekko dilakukan akibat overtopping dan pipping menggunakan aplikasi Zhong Xing HY21 yang dapat menghasilkan peta penyebaran genangan banjir sehingga dapat digunakan untuk pedoman penetapan batasan potensi daerah terdampak bencana. Hal ini merupakan salah satu upaya mengurangi dampak kerugian dengan mengetahui kondisi wilayah terdampak keruntuhan bendungan.

\section{Bahan dan Metode}

Bagian bahan dan metode, atau dikenal sebagai metodologi penelitian, menjelaskan semua informasi yang diperlukan untuk mendapatkan hasil penelitian

\subsection{Bahan}

\section{A. Gambaran Umum Lokasi Studi}

Bendungan Salomekko terletak di Dukuh Salomekko Desa Ulu Balang, Kecamatan Salomekko, Kabupaten Bone, Provinsi Sulawesi Selatan. Secara geografis Kabupaten Bone terletak di pesisir Timur Provinsi Sulawesi Selatan dan memiliki luas wilayah sekitar 4,559 $\mathrm{km}^{2}$ atau 9,78\% dari luas Provinsi Sulawesi Selatan. Selain itu, bagian barat Teluk Bone sangat menjanjikan apabila ingin dikembangkan karena mempunyai sumber daya alam yang melimpah. Sedangkan secara astronomis Kabupate Bone terletak antara koordinat 119 $42^{\prime}$ sampai 120 30' Bujur Timur dan 4 $4^{\circ} 13^{\prime}$ sampai $5^{\circ} 6^{\prime}$ Lintang Selatan.

Bendungan Salomekko berada dalam Daerah Aliran Sungai Salomekko yang merupakan DAS kecil yang berbatasan dengan sebelah utara DAS Salo Baruttung dan DAS Salo Rumpai, sebelah barat DAS Salo Bulubulu dan DAS Salo Batakao, sebelah selatan DAS Salo Jawijawi, sebelah timur Teluk Bone. Peta dari pemerintah Kabupaten Bone tentang daerah aliran sungai di Kabupaten Bone ditunjukan pada (Gambar 1), dimana Sungai Salomekko di bagian hulu bendungan terbentuk dari 3 anak sungai utama, dengan panjang sungai utama sampai lokasi bendungan 6,5 km [2]. Sungai Salomekko mengalir dari Barat ke arah Timur, dan bermuara di Teluk Bone. Panjang Sungai Salomekko dari bendungan ke muara adakah sekitar $11.8 \mathrm{~km}$. DAS Salomekko memiliki luas 40,5 km². Sedangkan Daerah Tangkapan Air Bendungan Salomekko mempunyai luas 13,2 km². 


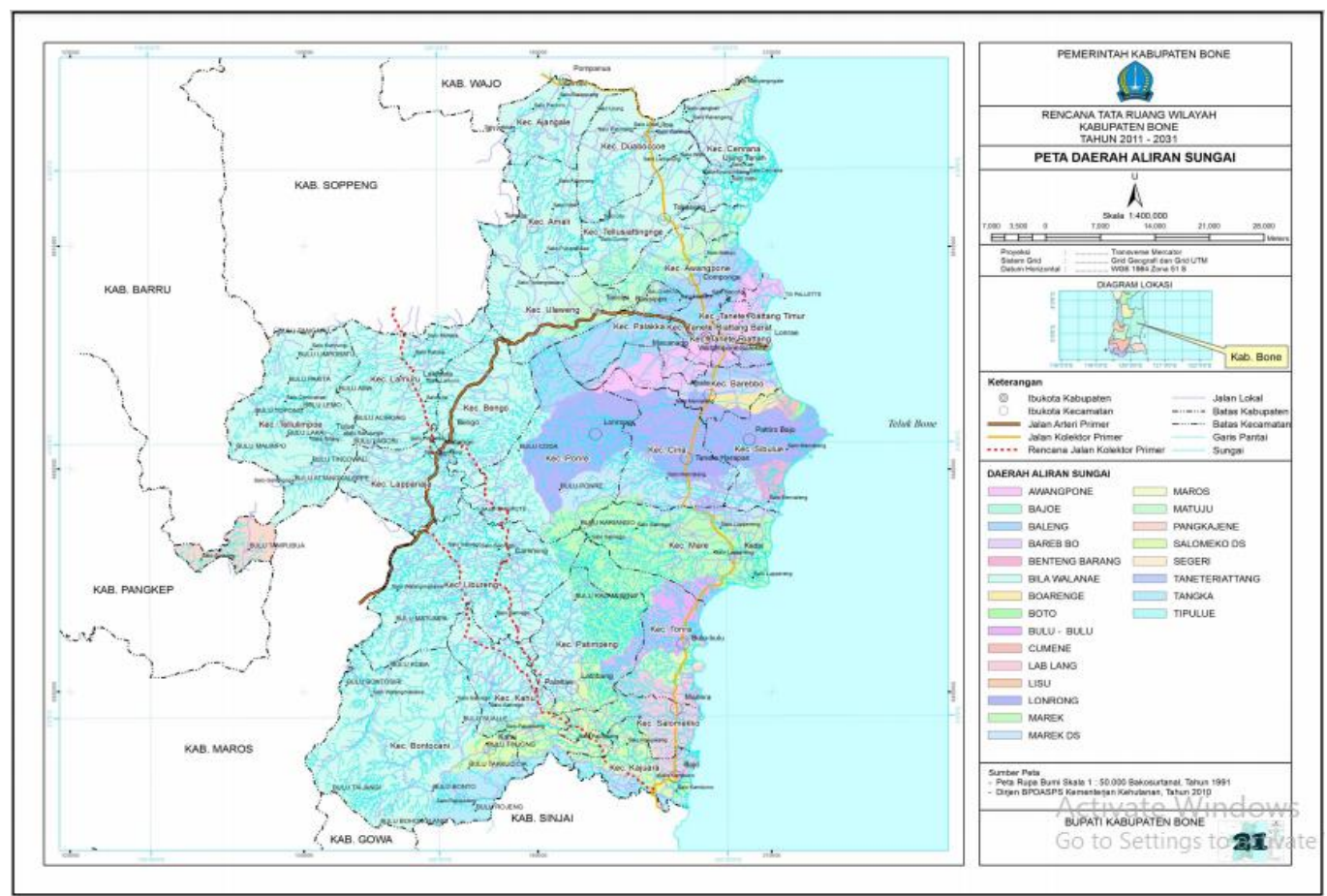

Gambar 1: Peta Daerah Aliran Sungai di Kabupaten Bone

B. Data Penelitian

Dalam studi ini dibutuhkan data untuk analisa Keruntuhan Bendungan Salomekko yaitu :

- Data Hujan Harian Maksimum Tahunan

Data hujan digunakan sebagai data pokok dalam perhitungan debit banjir rancangan yang terdapat pada Waduk Salomekko. Dalam hal ini Terdapat satu stasiun hujan yang terdekat dipilih mewakili DAS Salomekko yaitu Stasiun Hujan Salomekko (Bicoing). Data huan yang digunakan selama 20 tahun dari tahun 2000-2019.

- Data Teknis Bendungan Salomekko

Data teknis bendungan digunakan untuk mengetahui karakteristik Bendungan Salomekko.

- Lengkung kapasitas Waduk Salomekko

Untuk mengetahui kapasitas Waduk Salomekko yang berfungsi unuk perhitungan penelusuran banjir di atas pelimpah sehingga didapat elevasi waduk ketika banjir.

- Peta Isohyet PMP Kabupaten Bone Sulawesi Selatan.

Peta PMP digunakan untuk mencari nilai Probable Maximum Precipitation (PMP) yang sudah digambarkan di Bendungan Salomekko. Nilai ini nantinya dibandingkan dengan nilai Probable Maximum Precipitation (PMP) hitung untuk mendapatkan nilai debit banjir rencana Probable Maximum Flood (PMF).

- Peta topografi dan Data Elevation Model (DEM)

Hasil pengukuran topografi sungai bagian hilir Bendungan Salomekko digunakan untuk penggambaran kondisi bagian hilir bendungan pada aplikasi Zhong Xing HY21.

- Peta Rupa Bumi Indonesia (RBI) Kabupaten Bone Sulawesi Selatan

Peta RBI digunakan untuk mengetahui daerah yang terkena dampak keruntuhan Bendungan Salomekko yang nantinya digunakan untuk mengetahui klasifikasi bahaya Bendungan Salomekko.

- Data bangunan dan Jalan Provinsi Sulawesi Selatan

Data bangunan dan jalan bagian hilir Bendungan Salomekko di Kabupaten Bone untuk mengetahui besaran dampak akibat keruntuhan Bendungan Salomekko.

- Data Jumlah Penduduk di Hilir Bendungan Salomekko

Untuk mengetahui klasifikasi atau tingkat bahaya dari keruntuhan Bendungan Salomekko. 


\subsection{Metode}

Untuk memperoleh debit maksimum (banjir) atau debit minimum (debit andalan) yaitu suatu nilai yang maksimal suatu besaran ekstrim, maka para pakar hidrologi harus mampu menginterpretasikan data yang tersedia dan diperuntukan bagi penelitiannya [3]. Analisis hidrologi ini bertujuan untuk memprediksi hujan dan debit banjir maksimum di Waduk Salomekko beserta perilakunya terhadap Bendungan Salomekko. Studi ini dimulai dari analisis hidrologi dengan menguji data hujan, analisis frekuensi, dan uji kesesuaian distribusi. Dalam analisis frekuensi debit banjir agar dapat diperiksa maka data yang digunakan setidaknya 20 tahun data pengamatan, serta mempelajari karakteristik dari fungsi distribusi data yang ada [4]. Setelah diperoleh curah hujan Probable Maximum Precipitation (PMP) kemudian data hujan PMP tersebut dikonversi menjadi debit dengan metode Hidrograf Satuan Sintetis (HSS) yang pada akhirnya diperoleh nilai debit banjir rancangan Probable Maximum Flood (PMF).

Selanjutnya data banjir disimulasikan melalui penelusuran banjir untuk memperoleh elevasi waduk pada debit banjir. Melalui penelusuran banjir tersebut akan diketahui apakah debit banjir tersebut dapat menyebabkan overtopping atau tidak. Hasil tersebut nantinya disimulasikan ke dalam program Zhong Xing HY21. Melalui hal tersebut didapatkan peta penyebaran banjir akibat keruntuhan Bendungan Salomekko sehingga dapat diketahui klasifikasi bahaya banjirnya.

\subsection{Persamaan}

\section{- Debit Banjir Rancangan}

Hidrograf satuan dipakai dalam sebuah analisis menentukan banjir rancangan apabila data yang tersedia merupakan data hujan. Metode ini cukup sederhana, mudah penerapannya, data yang diperlukan tidak rumit, dan hasil rancangan yang diberikan cukup teliti serta signifikan [5].

Persamaan HSS Nakayasu :

$$
\begin{array}{rlr}
Q_{p} & =\frac{A \cdot R_{0}}{3,6 \cdot\left(0,3 \cdot T_{p}+T_{0,3}\right)} & \text { Pers.1 } \\
T_{p}=t_{g}+0,8 t_{r} & \text { Pers.2 } \\
T_{0,3}=\alpha \cdot t_{g} & \text { Pers.3 } \\
\mathrm{t}_{\mathrm{r}}=0,5 \mathrm{t}_{\mathrm{g}} \text { sampai dengan } 1 \mathrm{t}_{\mathrm{g}}(\mathrm{jam}) & \text { Pers. } 4 \\
\mathrm{t}_{\mathrm{g}}=0,21 \mathrm{~L}^{0,7}(\text { untuk } \mathrm{L}<15 \mathrm{Km}) & \text { Pers. } 5
\end{array}
$$

Keterangan :

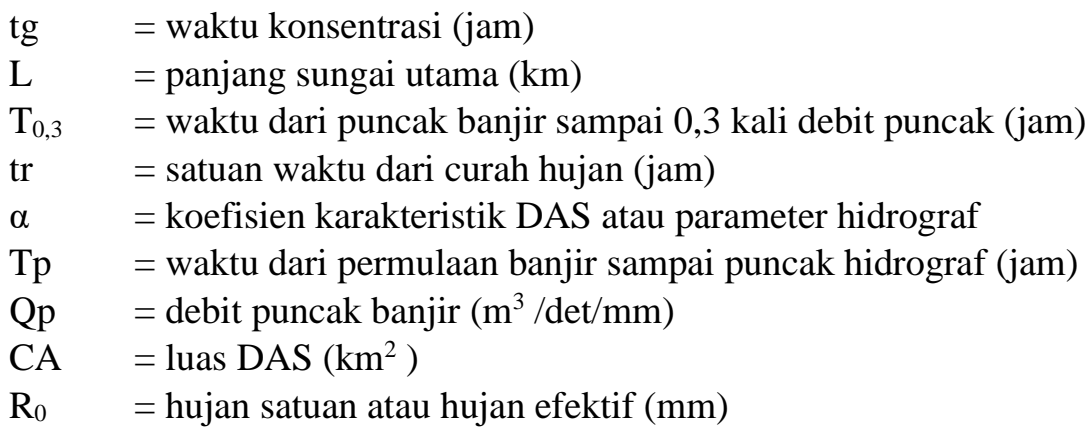

Persamaan HSS Limantara

$$
\begin{array}{cc}
\mathrm{Qp}=0,042 \cdot \mathrm{A}^{0,451} \cdot \mathrm{L}^{0,497} \cdot \mathrm{Lc}^{0,356} \cdot \mathrm{S}^{-0,131} \cdot \mathrm{n}^{0,168} & \text { Pers.6 } \\
\mathrm{Qn}=\mathrm{Qp} \cdot[(\mathrm{t} / \mathrm{Tp})]^{1,107} & \text { Pers.7 } \\
\mathrm{Qt}=\mathrm{Qp} \cdot 10^{0,175(\mathrm{Tp}-\mathrm{t})} & \text { Pers.8 } \\
\mathrm{Tp}=\operatorname{tg}+0,8 \operatorname{tr} & \text { Pers.9 } \\
\mathrm{L}<15 \mathrm{~km} \text {, maka tg }=0,21 \mathrm{~L}^{0,7} & \text { Pers. } 10
\end{array}
$$


Keterangan :

Qp = debit puncak banjir untuk hidrograf satuan $\left(\mathrm{m}^{3} / \mathrm{dt} / \mathrm{mm}\right)$

Qn = debit ketika persamaan kurva naik $\left(\mathrm{m}^{3} / \mathrm{dt} / \mathrm{mm}\right)$

Qt = debit Ketika persamaan kurva turun $\left(\mathrm{m}^{3} / \mathrm{dt} / \mathrm{mm}\right)$

A $\quad=$ luas pada DAS $\left(\mathrm{km}^{2}\right)$

$\mathrm{L} \quad=$ panjang sungai utama $(\mathrm{km})$

Lc = panjang sungai dari outlet sampai titik terdekat dengan titik berat DAS $(\mathrm{km})$

$\mathrm{S}=$ kemiringan sungai utama

$\mathrm{n} \quad=$ koefisien kekasaran DAS

$0,042=$ koefisien untuk konversi satuan $\left(\mathrm{m}^{0,25} / \mathrm{dt}\right)$

$\mathrm{Tp} \quad=$ waktu naik hidrograflatau waktu mencapai puncak hidrograf (jam)

$\mathrm{t} \quad=$ waktu hidrograf (jam)

$0,175=$ koefisien untuk konversi satuan $\left(\mathrm{dt}^{-1}\right)$

$\operatorname{tg} \quad=$ waktu konsentrasi hujan

tr $\quad=0,5$ tg sampai 1 tg

\section{- Penelusuran Banjir}

Untuk menentukan debit outflow maksimum dan tinggi air maksimum pada debit outflow dibutuhkan analisa penelusuran banjir di waduk. Penelusuran banjir pada waduk berguna untuk mengetahui apakah debit rancangan PMF pada waduk dapat mengalami overtopping atau tidak. Simulasi hanya dilakukan untuk kondisi piping atau pertimbangan lain apabila bendunga tersebut dinyatakan tidak mengelami overtopping ketika dilakukan penelusuran banjirnya. Tahapan penelusuran banjir pada dasarnya menggunakan persamaan kontinuitas massa aliran sederhana sebagai berikut:

$$
\mathrm{I}-\mathrm{O}=\frac{d s}{d t} \quad \text { Pers. } 11
$$

Metode perhitungan penelusuran banjir di waduk menggunakan persamaan :

Dimana:

$$
\mathrm{S}_{\mathrm{j}+1}-\mathrm{S}_{\mathrm{j}}=\left(\left(\mathrm{I}_{\mathrm{j}}+\mathrm{I}_{\mathrm{j}+1}\right) \Delta \mathrm{t}-\left(\left(\mathrm{Q}_{\mathrm{j}}+\mathrm{Q}_{\mathrm{j}+1}\right) / 2\right) \Delta \mathrm{t} \quad \text { Pers. } 12\right.
$$

$\mathrm{S}=$ Fungsi tampungan

$\mathrm{Q}=$ Hidrograf outflow

$\mathrm{I}=$ Hidrograf inflow

$\Delta \mathrm{t}=$ Interval durasi

Kurva hubungan antara elevasi muka air debit outflow melalui ambang spillway ditetapkan dari persamaan perhitungan hidrolika hubungan antara tinggi muka air dan perhitungan debit outflow:

$$
\mathrm{Q}=\mathrm{C} \mathrm{L} \mathrm{H}^{3 / 2} \quad \text { Pers. } 13
$$

Keterangan :

$\mathrm{Q}=$ Debit desain $\left(\mathrm{m}^{3} / \mathrm{dt}\right)$

$\mathrm{C}=$ Koefisien debit pelimpah $\left(1,7-2,2 \mathrm{~m}^{1 / 2} /\right.$ detik $)$

$\mathrm{L} \quad=$ Panjang mercu spillway $(\mathrm{m})$

$\mathrm{H}=$ Kedalaman muka air $(\mathrm{m})$

\section{- Keruntuhan Bendungan}

Gagalnya suatu bendungan diartikan sebagai keruntuhan sebagian, keseluruhan, atau hanya bangunan pelengkap, dan atau kerusakan yang menyebabkan bendungan tidak dapat berfungsi seperti yang seharusnya [6]. Menurut laporan Komisi Internasional Bendungan Besar, keruntuhan bendungan urugan umumnya terjadi 38\% akibat piping, 35\% akibat overtopping, 21\% akibat kegagalan pondasi, serta $6 \%$ lainnya [7]. Oleh karena itu pada studi ini keruntuhan bendungan hanya berdasarkan skenario overtopping (Gambar. 2) dan atau piping (Gambar. 3). 


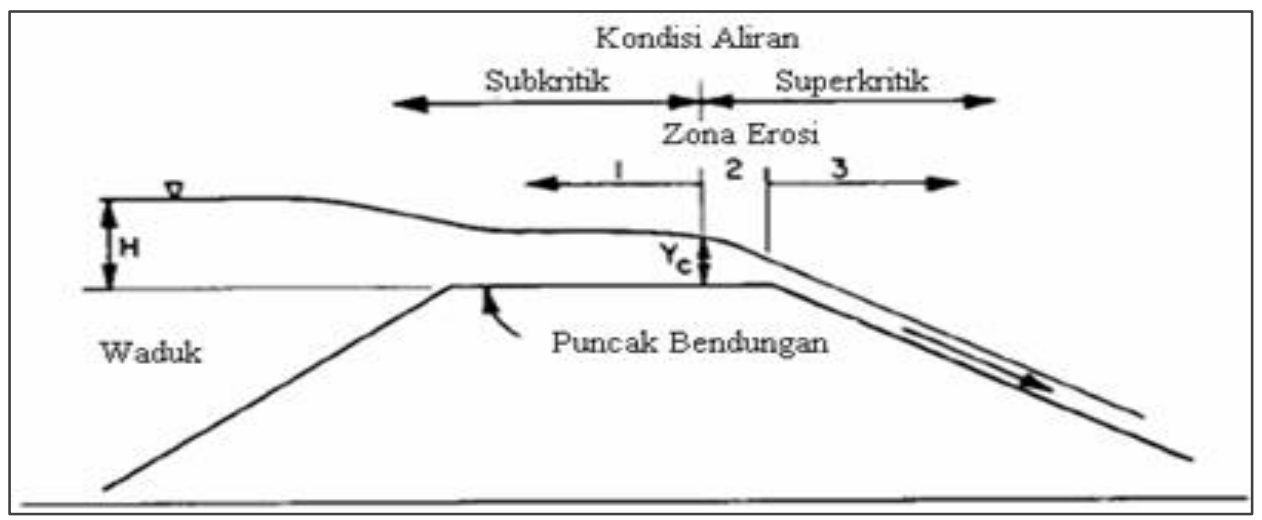

Gambar 2: Ilustrasi Keruntuhan Bendungan Akibat Overtopping

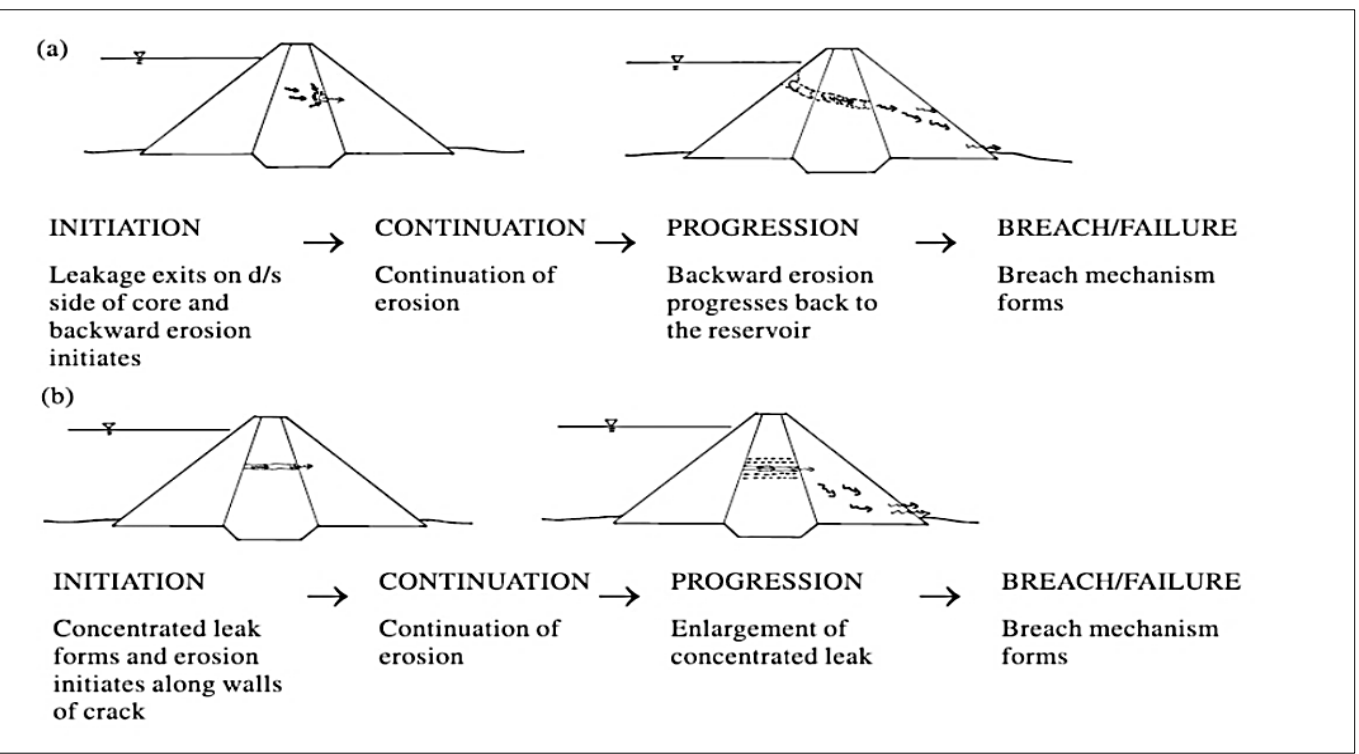

Gambar 3: Ilustrasi Keruntuhan Bendungan Akibat Piping

Skenario overtopping (Gambar. 2) digambarkan dengan rekahan berbentuk segiempat, trapesium, atau segitiga. Rekahan akan membesar seiringnya waktu, dimulai dari puncak tubuh bendungan hingga mencapai pondasi bendungan. Aliran yang digambarkan dan diperhitungkan melewati rekahan dengan skenario overtopping ini adalah sebagai suatu aliran yang melewati ambang lebar [8]. Sedangkan kegagalan piping umumnya memiliki rekahan berbentuk persegi empat yang diawali dengan merembesnya air melalui material, kemudian lubang yang lebih besar terbentuk, sehingga mampu membawa lebih banyak air dan mengikis lebih banyak material. Berikut gambaran dari parameter rekahan (Gambar. 4) pada proses keruntuhan bendungan [9].

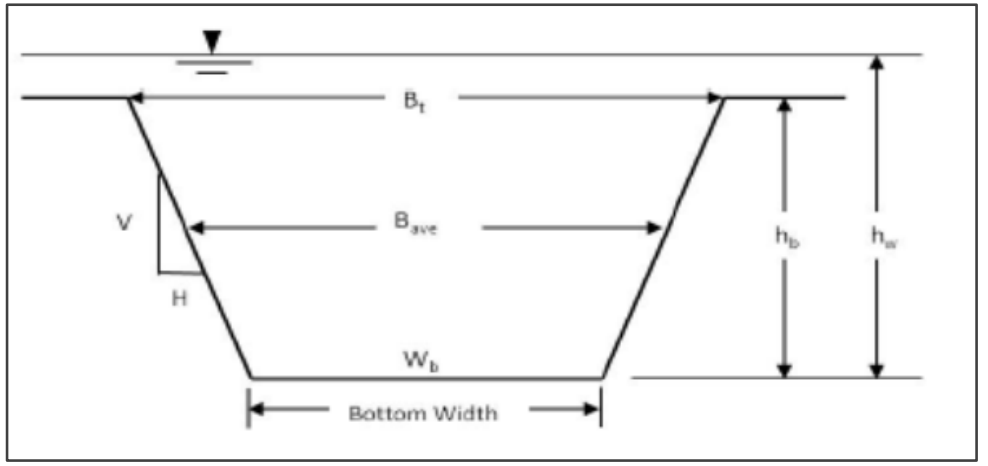

Gambar 4: Gambaran Parameter Rekahan 
Persamaan regresi Froechlich (2008) untuk lebar rata-rata rekahan dan waktu keruntuhan yaitu :

$$
\begin{array}{cc}
\mathrm{B}_{\mathrm{ave}}=0,27 \cdot \mathrm{K}_{0} \cdot \mathrm{Vw}^{0,32} \cdot \mathrm{hb}^{0,04} & \text { Pers. } 14 \\
\mathrm{tf}=63,2 \sqrt{\frac{V w}{g h b^{2}}} & \text { Pers. } 15
\end{array}
$$

Keterangan :

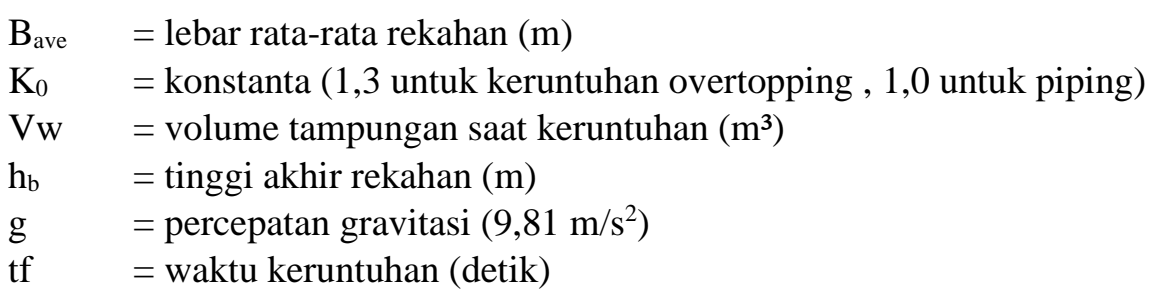

Menurut peneliti bernama Frolechlich mengatakan bahwa lereng sisi rata-rata seharusnya $1.0 \mathrm{H}$ : $1 \mathrm{~V}$ untuk keruntuhan overtopping dan $0,7 \mathrm{H}: 1 \mathrm{~V}$ untuk keruntuhan lainnya (seperti piping). Meskipun tidak secara jelas dinyatakan dalam makalah oleh Froechlich, ketinggian dari keruntuhan biasanya dihitung dengan mengasumsikan bahwa keruntuhan berjalan dari atas bendungan hingga ke ketinggian tanah alami di lokasi teradinya suatu keruntuhan bendungan [10].

\section{- Aplikasi Zhong Xing HY21}

Aplikasi Zhong Xing HY21 adalah perangkat lunak yang mensimulasikan suatu keruntuhan bendungan, dan menghasilkan sebuah hidrograf aliran keluar (Outflow Hidrograf), dan mampu membuat simulasi gerakan gelombang banjir yang disebabkan runtuhnya suatu bendungan (Dam Break Analysis). Kemampuan yang dimiliki oleh aplikasi Zhong Xing HY21 adalah sebagai berikut:

a. Kemampuan mensimulasikan yang dipengaruhi alur sungai yang bermeander dalam dataran banjir yang cukup lebar.

b. Kemampuan melakukan simulasi aliran yang subkritis dan superkritis untuk routing yang sama.

c. Kemampuan routing sebuah hidrograf menggunakan dynamic routing yang cepat serta baik, untuk beragam skenario keruntuhan bendungan.

d. Kemampuan simulasi terpengaruh breakwater akibat kehancuran atau kegagalan pada bendungan yang mempertemukan anak sungai dengan sungai.

e. Kemampuan untuk menciptakan animasi perjalanan banjir, waktu tiba banjir, dan waktu surut banjir. Aplikasi Zhong Xing HY21 memiliki banyak kelebihan yang dapat digunakan, tetapi aplikasi ini juga memiliki beberapa keterbatasan sebagai berikut:

a. Hasil dari simulasi tidak mampu dijamin $100 \%$ secara akurat.

b. Hasil dari simulasi tidak mampu menghasilkan hasil genangan akhir atau tidak bisa menghitung waktu banjir surut.

c. Simulasi dari hasil keruntuhan bendungan tidak mampu dilakukan hanya dengan sekali proses saja.

d. Alur sungai yang berada di hilir suatu bendungan pada dasarnya tidak bisa kering pada awal simulasi, sehingga wajib memiliki aliran dasar meskipun sangat kecil.

\section{- Klasifikasi Tingkat Bahaya}

Dalam penelitian ini, penentuan tingkat klasifikasi bahaya menggunakan pedoman Surat Keputusan Dirjen SDA Nomor 257/KPTS/D/2011, tentang Klasifikasi Bahaya Bendungan dimana kriteria penetapan tingkat bahaya banjir akibat keruntuhan suatu bendungan menggunakan dan mempertimbangkan parameter PenRis (penduduk yang terkena resiko) terhadap jarak suatu bendungan, ketinggian genangan banjir, dan kecepatan banjir. Berikut (Tabel 1) menunjukan klasifikasi tingkat bahaya bedasarkan banyaknya penduduk terkena resiko akibat keruntuhan bendungan yang bersumber pada peraturan Kementerian Pekerjaan Umum Direktorat Jenderal Sumber Daya Air [11]. 
Tabel 1 : Kriteria Penetapan Tingkat Bahaya Banjir Akibat Keruntuhan Bendungan

\begin{tabular}{cccccc} 
Jumlah Penduduk Terkena Resiko & \multicolumn{5}{c}{ Jarak dari Bendungan $(\mathrm{km})$} \\
\cline { 2 - 6 } (PenRis) & $0-5$ & $0-10$ & $0-20$ & $0-30$ & $0->30$ \\
\hline 0 & 1 & 1 & 1 & 1 & 1 \\
$1-100$ & 3 & 3 & 2 & 2 & 2 \\
$101-1000$ & 4 & 4 & 4 & 3 & 3 \\
$>1000$ & 4 & 4 & 4 & 4 & 4 \\
\hline
\end{tabular}

Keterangan Tabel 1 :

klasifikasi bahaya bernilai 1 = bahaya tingkat rendah

klasifikasi bahaya bernilai 2 = bahaya tingkat sedang

klasifikasi bahaya bernilai 3 = bahaya tingkat tinggi

klasifikasi bahaya bernilai 4 = bahaya tingkat sangat tinggi

\section{Hasil dan Pembahasan}

\subsection{Analisis Hidrologi}

Bedasarkan peta PMP Sulawesi Selatan, nilai PMP yang terjadi di lokasi Bendungann Salomekko sebesar $770 \mathrm{~mm}$. Sedangkan bedasarkan PMP Hitung metode Hersfield bernilai lebih besar dari pada PMP Isohiet yaitu sebesar 950,387 mm. Sehingga hasil PMP Hitung metode Hersfield dipilih untuk digunakan dalam proses perhitungan selanjutnya.

Tabel 2 : Rekapitulasi Hidrograf Satuan Sintetis

\begin{tabular}{ccc}
\hline \multirow{2}{*}{ Metode HSS } & \multicolumn{2}{c}{ Rekapitulasi Debit Banjir Rancangan $\left(\mathrm{m}^{3} / \mathrm{dt}\right)$} \\
\cline { 2 - 3 } & 1000 th & PMF \\
\hline Nakayasu & 312,581 & 753,862 \\
Limantara & 94,440 & 565,528 \\
\hline
\end{tabular}

Bedasarkan hasil perhitungan debit banjir rancangan (Tabel 2) di atas, dinyatakan bahwa nilai debit banjir rancangan metode HSS Nakayasu lebih besar dibanding metode limantara. Sehingga nilai yang digunakan adalah nilai debit banjir rancangan metode HSS Nakayasu dengan $\mathrm{Q}_{1000}$ sebesar 312,581 $\mathrm{m}^{3} /$ detik dan $\mathrm{Q}_{\mathrm{PMF}}$ sebesar 753,862 $\mathrm{m}^{3} /$ detik.

\subsection{Penelusuran Banjir (Flood Routing) Melalui Pelimpah}

Bedasarkan hasil flood routing $\mathrm{QPMF}_{\mathrm{PM}}$ (Gambar 5), didapatkan elevasi maksimum sebesar $+80,52 \mathrm{~m}$ yang telah melewati pelimpah dengan elevasi $+76,00 \mathrm{~m}$. Dengan elevasi puncak bendungan $+80,00 \mathrm{~m}$, sehingga untuk kondisi banjir QPMF maka Bendungan Salomekko mengalami overtopping.

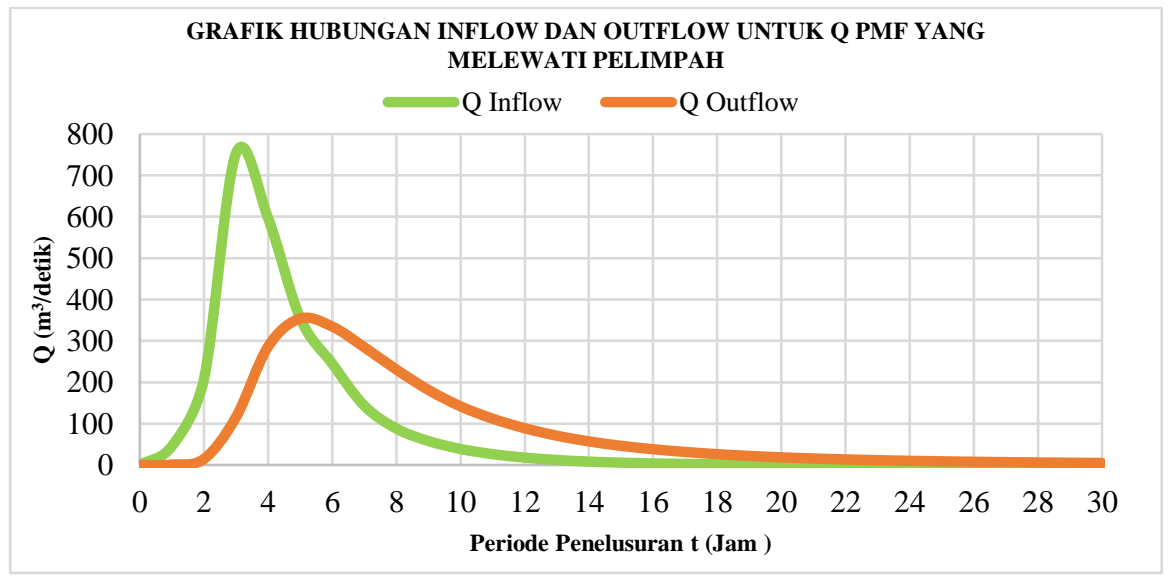

Gambar 5 : Grafik Hubungan Inflow dan Ouflow Pada Pelimpah Untuk QPMF 


\subsection{Hasil Simulasi Aplikasi Zhong Xing HY21}

Dilakukan simulasi untuk skenario piping atas, piping tengah, piping bawah, dan overtopping. Sehingga didapatkan karakteristik banjir akibat keruntuhan Bendungan Salomekko berbeda untuk setiap skenario keruntuhan.

Tabel 3 : Hasil Simulasi setiap Skenario dari Aplikasi Zhong Xing HY21

\begin{tabular}{cccc}
\hline $\begin{array}{c}\text { Skenario } \\
\text { Keruntuhan }\end{array}$ & $\begin{array}{c}\text { Jumlah Desa } \\
\text { Terdampak }\end{array}$ & $\begin{array}{c}\text { Luas } \\
\text { Genangan } \\
\left(\mathrm{Km}^{2}\right)\end{array}$ & $\begin{array}{c}\text { Total Debit Outflow } \\
\text { Puncak Saat } \\
\text { Keruntuhan Terjadi } \\
\left(\mathrm{m}^{3} / \mathrm{det}\right)\end{array}$ \\
\hline $\begin{array}{c}\text { Piping Atas } \\
\text { Kondisi Muka } \\
\text { Air Banjir }\end{array}$ & 11 & 13,732 & 1739,47 \\
$\begin{array}{c}\text { Piping Tengah } \\
\text { Kondisi Muka } \\
\text { Air Banjir }\end{array}$ & 11 & 14,478 & 6412,289 \\
$\begin{array}{c}\text { Piping Bawah } \\
\text { Kondisi Muka } \\
\text { Air Banjir }\end{array}$ & 11 & 14,932 & 7613,555 \\
Overtopping & 11 & 15,694 & 8357,593 \\
\hline
\end{tabular}

Bedasarkan hasil simulasi pada setiap skenario (Tabel 3) didapatkan bahwa skenario overtopping memberikan dampak banjir terbesar. Sehingga berikut disajikan klasifikasi tingkat bahaya banjir akibat kondisi overtopping (Tabel 4).

Tabel 4: Klasifikasi Tingkat Bahaya Banjir Berdasarkan Penduduk Terkena Resiko

\begin{tabular}{ccccccc}
\hline No & Desa & $\begin{array}{c}\text { Jarak } \\
\text { Dari } \\
\text { Bendungan } \\
(\mathrm{km})\end{array}$ & $\begin{array}{c}\text { Rumah } \\
\text { Terdampak }\end{array}$ & $\begin{array}{c}\text { Jumlah } \\
\text { Penduduk } \\
\text { Terkena } \\
\text { Resiko } \\
\text { (Jiwa) }\end{array}$ & $\begin{array}{c}\text { Klasifikasi } \\
\text { Bahaya }\end{array}$ & Keterangan \\
\hline 1 & Bicoing & 2,618 & 164 & 820 & 4 & Bahaya Sangat Tinggi \\
2 & Bacu & 5,250 & 108 & 540 & 4 & Bahaya Sangat Tinggi \\
3 & Pancatana & 6,520 & 44 & 220 & 4 & Bahaya Sangat Tinggi \\
4 & Muara & 6,170 & 79 & 395 & 4 & Bahaya Sangat Tinggi \\
5 & Bonepetu & 7,180 & 0 & 0 & 1 & Bahaya Rendah \\
6 & Ujunge & 7,450 & 0 & 0 & 1 & Bahaya Rendah \\
7 & Tebba & 6,380 & 36 & 180 & 4 & Bahaya Sangat Tinggi \\
8 & Manera & 6,913 & 82 & 410 & 4 & Bahaya Sangat Tinggi \\
9 & Mapatoba & 9,120 & 0 & 0 & 1 & Bahaya Rendah \\
10 & Malimongeng & 10,190 & 0 & 0 & 1 & Bahaya Rendah \\
11 & Tarasu & 11,090 & 0 & 0 & 1 & Bahaya Rendah \\
\hline
\end{tabular}

Bedasarkan klasifikasi tingkat bahaya banjir akibat kondisi overtopping (Tabel 4), didapatkan bahwa terdapat 6 desa yaitu Desa Bicoing, Desa Bacu, Desa Pancatana, Desa Muara, Desa Bonepetu, Desa Tebba, dan Desa Manera yang klasifikasinya tergolong bahaya sangat tinggi. Sedangkan 5 desa lainnya yaitu Desa Bonepetu, Desa Ujunge, Desa Mapatoba, Desa Malimongeng, dan Desa Tarasu yang klasifikasinya tergolong bahaya rendah karena tidak padat penduduk. Jumlah seluruh penduduk yang terkena resiko pada bagian hilir Bendungan Salomekko memiliki total penduduk sejumlah 2565 jiwa. 


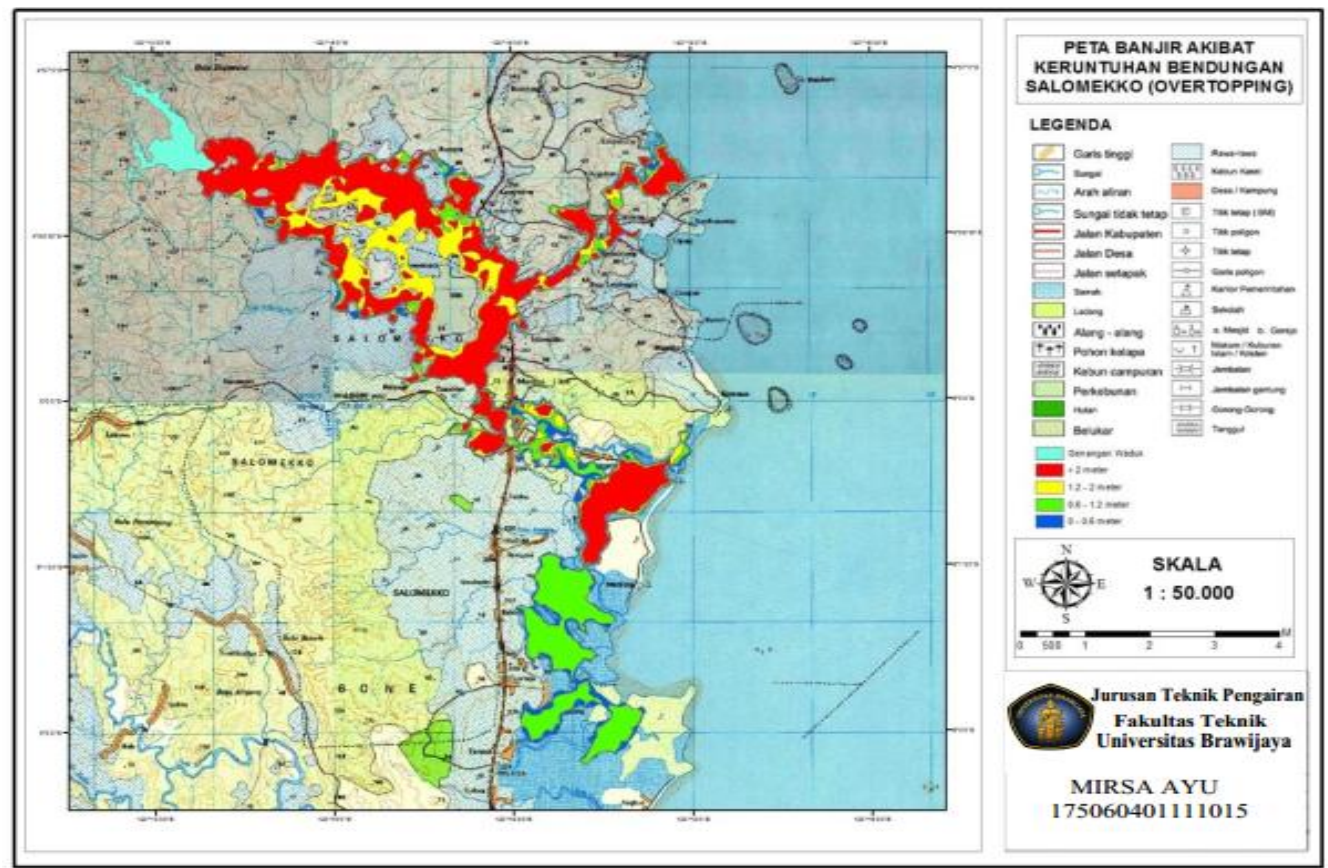

Gambar 6 : Peta Genangan Banjir akibat Kondisi Overtopping

Pada peta sebaran genangan banjir akibat kondisi overtopping (Gambar 6) yang tersebar ke 11 desa. Genangan banjir bewarna merah menunjukan kedalaman air lebih dari $2 \mathrm{~m}$. Hal ini menunjukan bahwa banjir akibat keruntuhan bendungan kondisi overtopping akan memberikan dampak paling besar.

\section{Kesimpulan}

Bedasarkan simulasi, didapatkan bahwa debit banjir dengan kala ulang QPMF sebesar 753,862 m³/det dapat menyebakan Bendungan Salomekko mengalami kerruntuhan akibat overtopping. Sehingga skenario keruntuhan bendungan diasumsikan mengalami piping dan overtopping, dengan kondisi paling ekstrem yakni kondisi overtopping. Dengan luas genangan 15,694 $\mathrm{km}^{2}$ dan kedalaman banjir yang cukup besar, kondisi overtopping mampu menyebarkan banjir ke 11 desa yang 6 desa diantaranya tergolong klasifikasi tingkat bahaya banjir sangat tinggi.

\section{Ucapan Terima kasih}

Terimakasih kepada PT. Caturbina Guna Persada, yang telah berkontribusi besar dalam penelitian ini. Yakni dalam pemberian seluruh data yang dibutuhkan untuk perhitungan dan peminjaman aplikasi Zhong Xing HY21 untuk melakukan simulasi keruntuhan Bendungan Salomekko. Selain itu terimakasih diucapkan pula, atas petunjuk penggunaan aplikasi Zhong Xing HY21 yang diberikan.

\section{Daftar Pustaka}

[1] S. G. Aniskurillah, R. Asmaranto, P. T. Juwono, "Analisa Keruntuhan Bendungan Muka Kuning Batam Menggunakan Aplikasi Zhong Xing HY21,” vol. 28, no. 12, pp. 1286-1290, 2013.

[2] Pemerintah Kabupaten Bone, "Buku Putih Sanitasi Kabupaten Bone,” pp. 16-62, 2013.

[3] C. D. Soemarto. Ir. B.I.E. DIPL.H., "Hidrologi Teknik Edisi Ke - 2,” Erlangga : Jakarta, 1997.

[4] Badan Standardisasi Nasional, "SNI 2415:2016 - Tata cara perhitungan debit banjir rencana," 2016.

[5] T. Bambang, "Hidrologi terapan," Beta Offset, Yogyakarta, vol. 59, p. 50, 2008. 
[6] Y. P. Sasongko and P. T. Juwono, "Analisa Keruntuhan Bendungan Kuningan Dengan Menggunakan Program Zhong Xing HY21,”, vol. 5, pp. 110-118, 2018.

[7] W. B. Technical, G. Le Moigne, S. Barghouti, and H. Plusquellec, Dam Safety and the Environment, no. 115. .

[8] L. C. Rachmadan, P. T. Juwono, and R. Asmaranto, "Analisa Keruntuhan Bendungan Alam Way Ela Dengan Menggunakan Program Zhong Xing Hy21,” vol. 7, no. 2002, pp. 1-6, 2015.

[9] G. Brunner, "Using HEC-RAS for Dam Break Studies, TD-39," Us Army Corps Eng. Hydrol. Eng. Cent., no. August, p. 74, 2014.

[10] G. W. Brunner and CEIWR-HEC, "HEC-RAS River Analysis System User's Manual," no. February, p. 1442, 2016.

[11] Kementerian Pekerjaan Umum Direktorat Jenderal Sumber Daya Air, "Pedoman Teknis Klasifikasi Bahaya Bendungan.” Jakarta, 2011. 